報 文

[Nippon】Nôgeikagaku Kaishi Vol.58, No.6, pp. 545〜551, 1984]

\title{
糠床熟成中の酵母フローラの消長と 分離菌株の同定
}

\author{
今井正武, 後藤昭二* \\ (森永製菒株式会社研究所, *山梨大学発酵化学研究施設)
}

昭和 58 年 9 月 30 日受理

\author{
Aging of "Nukadoko": Changes in Yeast Flora and \\ Identification of the Isolates \\ Masatake IMAI and Shoji GoTO* \\ Research Institute, Morinaga \& Co., 2-1-1, Shimosueyoshi, \\ Tsurumi-ku, Yokohama 230 \\ * The Institute of Enology and Viticulture, Yamanashi University, \\ 1-13-1, Kitashin, Kofu 400
}

\begin{abstract}
Changes in yeast flora of "Nukadoko" (mixture of rice bran and salt used for vegetable pickling) were followed during 120 days, and the isolated yeasts were identified. The aging response at 2 years was also examined. Yeasts were not detected in fresh "Nukadoko," but after 30 days the total count of yeast reached $1.2 \times 10^{6}$ colonies $/ g$ and after 60 days, $5.9 \times 10^{7} / \mathrm{g}$. After reaching a maximum count, the yeast showed a noticeable decrease and reached a stable level of $1 \times 10^{6}$ colonies/g, almost the same level as 2 year-aged "Nukadoko."

Candida krusei, Torulopsis etchellsii, Candida lipolytica, Rhodotorula minuta and Candida sp. were detected in the representative 64 isolated strains of "Nukadoko" at the tested periods. At all aging periods, C.krusei was dominant and reached $50 \sim 67 \%$ of flora, and T.etchellsii was second with $20 \sim 30 \%$. Candida sp. was detected at $10 \%$ only before aging for 90 days. C. lipolytica was detected only after aging for 90 days. Thus, 90 days seems near the alternation point between these species. The rate of the main yeast flora at the bottom of "Nukadoko" aged for 120 days was almost the same as that of 2 year-aged "Nukadoko." The flavors produced by pure cultures of isolated C.krusei, C. lipolytica and T.etchellsii resembled flavors in aged "Nukadoko". Candida sp. produced a "Malted rice" flavor. (Received September 30, 1983)
\end{abstract}

緒

言

糠みそ漬はわが国の伝統的な漬物で，その独特な香味 は他の漬物にみられない複雄さがあり，その香味に至る までには長期間を要することが知られている。しかし， その間の改生物相や成分の変化については，ほとんど明 らかにされていない，糠みそ床の微生物闰関しては，支 倉が(1,2)乳酸菌 Lactobacillus plantarum を，また，酵母 については小崎(3)が Pichia, Debaryomyces, Zygosac- charomyces 分離，報告している，

著者らの一人は，先に粶床の熟成過程に和ける微生物 相，主に乳酸菌群とグラム陰性菌群についで (4)，をた， フレーバ一成分の变化についで(5)報告した.

本報では棣床熟成中の醅母フローラの消長と熟成香生 成との関連を検討 し，また，分離醏母菌株の同定を行っ たので，それらの結果を報告する。 


\section{実 験 方 法}

1. 糠床の調製市股生糖 $3.0 \mathrm{~kg}$, 並塩 $0.72 \mathrm{~kg}$, 水道水 $5.25 \mathrm{~kg}$ 支 $10 \mathrm{l}$ 容の蓋付プラスチックパケッに 入れ，混合し綠床とした。

清潔な手で2日に1日，十分に攪拌し，その時，洗浄 したキュウり 2 本（約 $200 \mathrm{~g}$ ）とナス 1 個（約 $80 \mathrm{~g}$ )を 24 時間漬けた後取り出し再びキュウリとナスを漬けた。 この操作を 120 日後まで続けて糠床試料とした。別に, 上記同様の配合で調彆した棣床に野菜の種類を限定せず に2〜3日ごとに瀆け，2力月間隔で食塩 $75 \mathrm{~g}$ ，生糠 $250 \mathrm{~g}$ を補添し，らまい清物がでるる状態を室温で 2 年 間保ち， 2 年後の陚料とした。

2. 試料の採取 嵻床から，30 日間隔で 120 日後 まで，約 $300 \mathrm{~g}$ の糠床試料を十分攪扫した後採取し，微 生物検定特よび分析用試料とした. 2 年後の糠床からも $300 \mathrm{~g}$ を採取して供試した。

3. 総酵母数の計数之分離 試料糠床 $10 \mathrm{~g}$ 在隇菌 生理食塩水 $50 \mathrm{ml}$ に惩濁 し，さらに食塩水で $10^{-1} \sim 10^{-7}$ に希䣋し，クロラムフェニコール添加 $\mathrm{MY}$ 寒天培地 ${ }^{(4)}$ を用いて $25^{\circ} \mathrm{C}, 5$ 日間平板培差後，コロニ一数を計数し， 総酵母数をコロ

熟成 120 日までの各熟成期ごとの醉母の分離, 選択方 法については，熟成 60 日，120日表層部および 2 年後 の試料以外は， $10^{-5}$ 希秎で 1 平板当り 10 個前後のコロ ニー数であったので，平板 3 枚分の全コロニー，約 30 㮯を鈎菌した。熟成 60 日の試料については，10-6 希釈 で 1 平板当り 50〜70 個のコロニー数であったので， 1 平板から無作為に 30 個のコロニーを鈎菌した。また， 120 日表層部乙 2 年間熟成した試料については，1 平板 当り 10 個前後であったので，それぞれ 2 平板から無作 為に約 15 個のコロニーを鈎菌した。これらをクロラム $フ_{x}=コ ー ル$ 添加 MY 寒天平板を用いて平板培養を繰 り返し 149 菌株を得た。分離 149 菌株について，コロ ニーの形状, 細胞形態拈よびグルコース, ガラクトー ス, ショ糖, マルトース, 乳糖, ラフィノースの発䤃能 試験の結果から，類似菌株をそれぞれの分離菌株数の割 合に応して整理し，64菌株を選択して以後の荚験に供 した.

4. 分離酵母の群別と同定 供試酵母 64 株につい

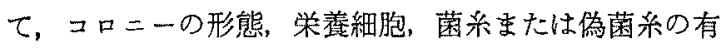
整と形状，有性生殖，発酵性，硝酸カリウムの資化性，
ウレアーゼ活性を調べ群別を行った。さらに各グループ 加ら選択した 13 菌株について, “The Yeasts,”2 nd ed. ${ }^{(6)}$ ，および飯塚，後藤 ${ }^{(7)}$ の方法に潐して同定試験を行

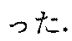

5. 糠床熟成香の生成試験 生捸 $20 \mathrm{~g}, 5 \%$ 食塩水 $180 \mathrm{ml}$ キュウリの絞り汁 $20 \mathrm{ml} 500 \mathrm{ml}$ 容三角フラ スコに入れ， $121^{\circ} \mathrm{C} ， 30$ 分間隇菌した.これと各分離醉 母を接種し，1週間ごとに 1 回，約 1 分間振と5しなが ら，25ㄷ $30 \mathrm{~g}$ を採取し糠床熟成香の生成の有無を官能的に判定 した。

\section{結果および考察}

\section{1. 熟成中の総酵母数の消長}

新しく調製した糠床に，野菜を漬け込みながらの熟成

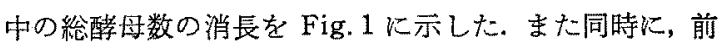
報 ${ }^{(4)}$ で得られた食塩，糖涨度，pH の变化も図示した。

この結果に示されるよらに，醉母は初発時の棣床には 検出されなかったが，30 日後には $1.2 \times 10^{6}$ コロニー/ $\mathrm{g}, 60$ 日後には $5.9 \times 10^{7} コ$ ロニ-/g に堌加した．以後， 総酵母数は減少し，90日および 120 日後にはそれぞれ $12 \times 10^{5}, 9.5 \times 10^{5}$ コロニー/g であった。また， 2 年間 熟成した槺床の総酵母数も，120日後のそれとほぼ同じ よらに $6.3 \times 10^{5}$ コロ=-/g であった. 以上のことか ら，酵母の急激な增殖は棣床熟成の初期に文られ，以後 熟成が進んた棣床では $10^{5} \sim 10^{6}$ コロニー/g に安定する

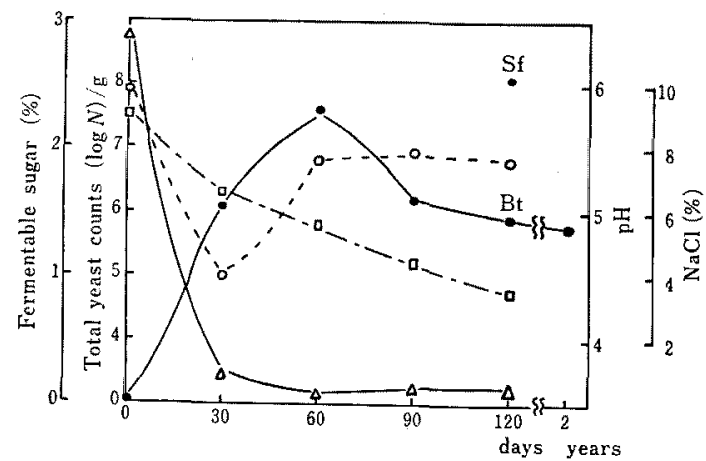

Fig. 1. Changes in Total Yeast Counts of the "Nukadoko" during Aging. O, total yeast counts ; $\triangle$, fermentable (sucrose and reducing sugar) sugar; $\mathrm{O}, \mathrm{pH} ; \square, \mathrm{NaCl}$; $\mathrm{Sf}$, total yeast counts on the surface of the "Nukadoko" left for 7 days without stirring; Bt, total yeast counts at the bottom of the "Nukadoko" on the same conditions as Sf. 
Table I. Percentage of Yeast Group in the "Nukadoko"a during Aging

\begin{tabular}{|c|c|c|c|c|c|c|}
\hline \multirow{3}{*}{ Yeast group (species) } & \multicolumn{5}{|c|}{ days } & \multirow{3}{*}{2 years } \\
\hline & \multirow{2}{*}{30} & \multirow{2}{*}{60} & \multirow{2}{*}{90} & \multicolumn{2}{|c|}{120} & \\
\hline & & & & $\widehat{B t^{b}}$ & $\widehat{S} f^{c}$ & \\
\hline Group 1 (Candida krusei) & $50 \%$ & $57 \%$ & $67 \%$ & $60 \%$ & $30 \%$ & $68 \%$ \\
\hline Group 2 (Torulopsis etchellsii) & 30 & 29 & 20 & 30 & 10 & 25 \\
\hline Group 3 (Candida lipolytica) & 0 & 0 & 6.5 & 10 & 60 & 7 \\
\hline Group 4 (Candida sp.) & 10 & 14 & 6.5 & 0 & 0 & 0 \\
\hline Group 5 (Rhodotorula minuta) & 10 & 0 & 0 & 0 & 0 & 0 \\
\hline
\end{tabular}

8. Raw rice bran $3.0 \mathrm{~kg}$, salt $0.72 \mathrm{~kg}$ and tap water $5.25 \mathrm{~kg}$ were thoroughly mixed in the 10 litervolume plastic jar with cover. It was stirred well every two days; then cucumbers (about 200g) and one egg plant (about $80 \mathrm{~g}$ ) were pickled in this "Nukadoko" for about $24 \mathrm{hr}$.

b The bottom of the "Nukadoko" left for 7 days without stirring.

"The surface of the "Nukadoko" on the same condition as Bt.

Table II. Production of Aging Flavor by Yeasts Isolated from "Nukadoko"

\begin{tabular}{lll}
\hline \multicolumn{1}{c}{ Yeasts } & \multicolumn{1}{c}{ Strains } & \multicolumn{1}{c}{ Flavor of the rice bran culture } \\
\hline Candida krusei & $\mathrm{M}-2,3,5,6,9,13$ & Weak, but resemble to aged "Nukadoko" \\
Torulopsis etchellsit & $\mathrm{M}-1,8,10$ & Fairy close to aged "Nukadoko" \\
Candida lipolytica & $\mathrm{M}-4,7$ & Weak, but resemble to "Nukadoko" \\
Candida sp. & $\mathrm{M}-11$ & Resemble to "Koji"b flavor \\
Rhodotorula minuta & $\mathrm{M}-12$ & No change \\
\hline
\end{tabular}

a A mixture of raw rice bran $(20 \mathrm{~g}), 5 \% \mathrm{NaCl}$ solution $(180 \mathrm{ml})$ and cucumber juice $(20 \mathrm{ml})$. It was autoclaved at $120^{\circ} \mathrm{C}$ for $30 \mathrm{~min}$ in $500 \mathrm{ml}$-volume flask. Each yeast isolated from "Nukadoko" was inoculated into the rice bran medium and cultured for 90 days.

b Malted rice.

ものと考えられる。

また，一般に熟成が進んだ嵻床を，夏期無㩈拌の状態 で数日間放監する上，㴍床表面は黒褐色の被膜状の層に 被われ，著しい悪臭を発することが知られている。Sfは そのモデルとして，120日熟成棣休を7日間放置したと きの表層部を意味する。また，120日 Btは同熟成期の 良好な熟成香を発する中心部を意味する。Fig.1亿示さ れるとおり，Sfでの酵母数は $1.4 \times 10^{8} コ ロ=-/ g$ も存 在し，正常な糠床を示す Btに比較して約 100 倍に達す る値を示した。

120 日閻の総酵母数の消長汇影響する要因として，糠

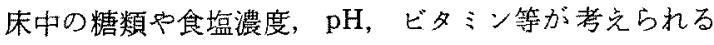
が，熟成初期から中期にかけての醉母の急激な增殖は， 共存する優勢な乳酸菌 ${ }^{(\mathbf{4})}$ こよる $\mathrm{pH}$ の低下や，この時期

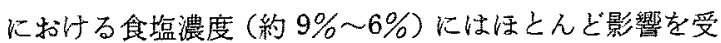
けていないよらに思われる。しかし，糖類（睘元糖およ びショ糖)の30日亮での急激な減少は，秏酸菌による 資化があるにせよ，醇母数の增大に密接な関係を持って いる上考兄られる，総醉母数の 60 日以降の減少は，糠

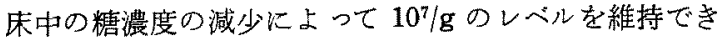

なくなったものと考劣られる。しかし，矢の後 $10^{5} \sim 10^{6}$ コロニー/g でほぼ一定の総醇母数を保っているのは, 棣床に 2 日に 1 回の割合で漬けられる新鮮な野菜からの ショ糖, ブドゥ糖等の少量の糖類, 扣よび糠の分解物か らの炭素源が補給されることによるものと考光られる。 またビタミンB群は棣のなかに多く含まれている(10)の で，初期から中期にか外ての粔休には，存在するビタミ ン要求珄微生物群の生育に少なから奴影響を与克ている 上考克られるが，Table I および Table III から明らか なよらに，菌相の主勢を占めるグループ1 (Candida krusei) およびグループ2（Torulopsis etchellsii）はど タミン要求性を持たないことから，60日までの熟成期 間での酵母総数の急激な増大には糖はど高い相関を有し ていないと推定される。

\section{2. 熟成中の酵母フローラの消長之熟成香の生成}

嵻床熟成の各ステージから分離した酵母 64 菌株は,

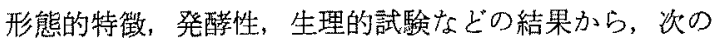

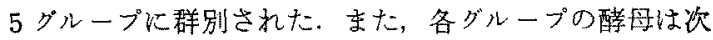
項に同定結果を記載したように，不完全型醅母の3属， 4 種まよび種末同定 1 株であっだ. 5 グループの形態的 
Table III. Physiological Properties of Strains Isolated from "Nukadoko"

\begin{tabular}{|c|c|c|c|c|c|c|c|c|c|c|c|c|c|c|c|c|c|c|c|}
\hline \multirow[b]{2}{*}{ 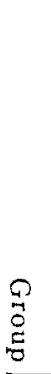 } & \multirow[b]{2}{*}{ Yeasts } & \multirow[b]{2}{*}{ Strains } & \multicolumn{6}{|c|}{ Fermentation } & \multirow{2}{*}{ 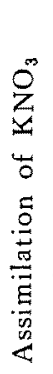 } & \multirow{2}{*}{ 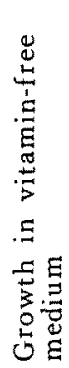 } & \multirow{2}{*}{ 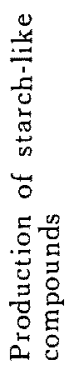 } & \multirow{2}{*}{ 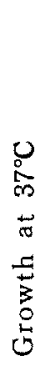 } & \multirow{2}{*}{ 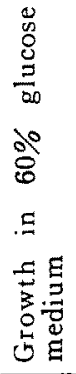 } & \multicolumn{4}{|c|}{ Growth in } & \multirow{2}{*}{ 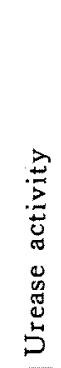 } & \multirow[b]{2}{*}{ } \\
\hline & & & 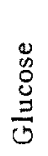 & 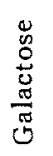 & 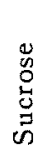 & 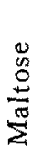 & $\begin{array}{l}0 \\
0 \\
0 \\
0 \\
0 \\
0 \\
0\end{array}$ & 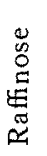 & & & & & & 6 & 9 & 15 & 18 & & \\
\hline 1 & Candida krusei & $\begin{array}{r}\mathrm{M}-2,3,5 \\
6,9,13\end{array}$ & + & - & - & - & - & - & - & + & - & + & + & + & + & $\begin{array}{c}+ \\
w\end{array}$ & - & $\underset{v w}{+}$ & - \\
\hline 2 & Torulopsis etchellsii & $M-1,8,10$ & + & - & - & + & - & - & + & + & - & - & + & + & + & + & + & - & - \\
\hline 3 & Candida lipolytica & $\mathrm{M}-4,7$ & - & - & - & - & - & - & - & + & - & - & - & + & $\begin{array}{l}+ \\
w\end{array}$ & - & - & + & + \\
\hline 4 & Candida sp. & M-11 & + & + & + & + & - & + & - & - & - & - & + & + & + & $\begin{array}{l}+ \\
w\end{array}$ & $+\frac{+}{w}$ & - & - \\
\hline 5 & Rhodotorula minuta & $\mathrm{M}-12$ & - & - & - & - & - & - & - & - & - & $\begin{array}{l}+ \\
w\end{array}$ & - & + & - & - & - & + & - \\
\hline
\end{tabular}

$w$, weak; vw, very weak.

特幑を示すと次のような結果であっだ.

Group 1 (Candida krusei) - white to cream-colored colonies of rough to wrinkled, cylindrical cells, well-developed pseudomycelium, fermentation ; Group 2 (Torulopsis etchellsii) - colonies of smooth and dull, small round cells, no pseudomycelium, fermentation, growth in $\mathrm{NaCl} 18 \%$; Group 3 (Candida lipolytica) cream-colored colonies of mucoid, wrinkled to coarsely folded, elongate cells, well-developed trueand pseudo-mycelium, no fermentation, splitting of fat ; Group 4 (Candida sp.) colonies of cream-colored, slightly powdery rough, formation of small oval polyblastic conidia on true- and pseudo-mycelium, fermentation; Group 5 (Rhodotorula minuta)-red colonies, oval cells, no pseudomycelium, no fermentation.

棣床熟成中の各グループの消長を，とれらの構成比と してTableI に表示した.この結果から明らかなように， ダループ1 (C. knusei) は熟成期間中，その構成比は

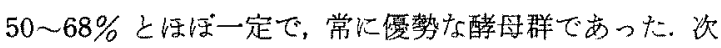
いでグループ 2 (T.etchellsii) 方各ステージから分離さ れ，構成比は全期間を通じて 20〜30\%とほぼ一定な醭 母群の一つであった。而グループは 2 年後の棣床でも共 通した傾向を示した。これらは Table III に示したよう に高い食盐酎性を持ら，また，Table II に示したよらに
熟成香の生成がみられるなど糈床中の重要な徽生物群の 一つと考えられる. とくに，グループ2（T. etchellsii) は熟成香心近い香気の生成加強く䆂床熟成に大きく関与 しているものと思われる。

グループ 3 (C. lipolytica) は初発後 60 日までは検出 されず，熟成の中，後期（90日以降）になって出現する といら特徴を示したすなわら，90日後で約 $7 \% ， 120$ 日で 10\%，また，2年後の䆂床にも $7 \%$ 検出され，出 現後は活匡一定の構成比を保つことを示した。これは， 本酵母の食填酎性が比較的低いことから，糠床中の経時 的な食塩分の減少によって構成比率が高くなってきたる のと考えられる。また，本群の酵母恉質の分解能を有 可る唯一の酵取群であり (Table III), 糠床熟成中のト リグリセライドの経時的な減少や熟成香気成分が脂質由 来の成分が多いこと柿から，本群の酵母が熟成香気生成 に関与しているおのと考えられる。また，120日後の潇 床を無攪䢁で放置した表層部 Sf には，総酔母数がグラ ム陰性菌とともに $10^{8}$ ユロニ一/g 以上に增大したが， その酔母菌相は良狈な熟成香を示す中心部 Btでのそれ とは異なり，C.lipolytica が最優勢であったことは與味 ある事实である。

グループ4 (Candida sp.) は, 前記のグループ1とは 逆に，㴍休調製後 30 日加ら 90 日の間にの文 6〜14\% の構成比で検出された。 しかし，120日および2年後の 熟成綠床からは全く検出されず，熟成の前，中期にのみ 
Table IV. Assimilation of Carbon Compounds by Strains Isolated from "Nukadoko"

\begin{tabular}{|c|c|c|c|c|c|}
\hline Carbon compounds & $\begin{array}{c}\text { Candida krusei } \\
(\mathrm{M}-2,3,5,6, \\
9,13)\end{array}$ & $\begin{array}{l}\text { Torulopsis } \\
\text { etchellsii } \\
(\mathrm{M}-1,8,10)\end{array}$ & $\begin{array}{l}\text { Candida } \\
\text { lipolytica } \\
(\mathrm{M}-4,7)\end{array}$ & $\begin{array}{l}\text { Candida } \mathrm{sp} . \\
(\mathrm{M}-11)\end{array}$ & $\begin{array}{c}\text { Rhodotorula } \\
\text { minuto } \\
(\mathrm{M}-12)\end{array}$ \\
\hline Glucose & + & + & + & + & + \\
\hline Galactose & - & $+w$ & - & + & $+w$ \\
\hline L-Sorbose & - & $+w$ & - & - & $+w$ \\
\hline Sucrose & - & - & - & + & + \\
\hline Maltose & - & + & - & + & - \\
\hline Cellobiose & - & - & - & + & $+w$ \\
\hline Trehalose & - & - & - & + & + \\
\hline Lactose & - & - & - & $+w$ & - \\
\hline Melibiose & - & - & - & + & - \\
\hline Raffinose & - & - & - & + & - \\
\hline Melezitose & - & - & - & + & + \\
\hline Inulin & - & - & - & + & - \\
\hline Soluble starch & - & - & - & + & + \\
\hline D-Xylose & - & - & - & - & - \\
\hline L-Arabinose & - & - & - & + & $+w$ \\
\hline D-Arabinose & - & - & - & - & + \\
\hline D-Ribose & - & $+w$ & $+\mathrm{vw}$ & + & - \\
\hline L-Rhamnose & - & - & - & + & - \\
\hline Ethanol & + & - & + & + & $+w$ \\
\hline Glycerol & + & + & + & + & - \\
\hline Erythritol & - & - & + & + & + \\
\hline Adonitol (Ribitol) & - & - & - & + & $+w$ \\
\hline Galactitol (Dulcitol) & - & - & - & - & - \\
\hline D-Mannitol & - & + & - & + & $+w$ \\
\hline D-Glucitol (Sorbitol) & - & $+w$ & - & + & $+w$ \\
\hline$\alpha$-Methyl-D-glucoside & - & - & - & + & - \\
\hline Salicin & - & - & - & - & $+w$ \\
\hline$d l$-Lactate & + & - & + & - & $+w$ \\
\hline Succinate & + & - & + & + & $+w$ \\
\hline Citrate & - & - & + & + & - \\
\hline Inositol & - & - & - & - & - \\
\hline 2-Keto-gluconate & - & $+w$ & - & & + \\
\hline 5-Keto-gluconate & - & - & - & & + \\
\hline Glucono- $\delta$-lactone & $+w$ & - & + & & - \\
\hline
\end{tabular}

w, weak; vw, very weak

出現するといら特徴的な分布を示した，本群の醅母は枹 類似の香気を生成した (Table II).

グループ 5 (Rhodotorula minuta) は，30日後の糠 床からのみ検出されたが，Table III から明らかなよう に，食塩 $6 \%$ では弱い生育しかみられなかった。この時 点での糠床は食塩 7〜9\% であり，本酵母はこれには生 育し難い之考方られ，野菜から持ち込まれたものと思わ れる。 また，本群の醳母は Table II に示したよらに，熟 成香生成試験では汪とんどフレーバーを生成しなかった ことから，熟成香生成に沙無係と考えられる。

以上の結果から,そのフローラは熟成初期から120日，
また 2 年後の糠床において，グループ 1 (C. knusei), グループ2（T.etchellsii）が主樊を占め，10\%棣培地で の純粋培養に赫いて，それぞれが糠床の熟成香に似た香 気を生成したことから，酵母群が熟成香生成にかなりの 影響を及ぼしていることが示唆されたまま，熟成の中 期でグループ 3 (C. lipolytica) とグループ4 (Candida sp.) との顕著な交替現象がみられたことは，すでに報し た 少なから関保があると考克られる。地，10\% 棣培地 での分離醭母の純粋培養路よび，他の菌との共生培着に 上る熟成香気成分の分析的結果については，現在検討中 
である。

\section{3. 分離酳母の同定・記載}

前記各醉母群の 64 菌株から選択した13 菌株は，群 別に用いた試験以外の生理的試験と詳細な炭素源の資化 結果から，以下のように 3 属 4 種および種末同定 1 株と 同定された。

供試菌株の生理的, 生化学的性状は Table III $と$ Table IV に示した。供試菌株はいす゚れも子の5胞子ゃ teliospore の形成といった有性生殖は諗められなか。 t. 形態的性状は “The Yeasts," 2 nd ed. (1970)(6) の各菌種の標準記载と大差がなかったので省略した。

\section{(1) Candida krusei (Cast) Berkhout}

菌株：M-2, $-3,-5,-6,-9,-13$

供試 6 菌株の生理, 生化学的性質は“The Yeasts” $(1970)^{(6)}$ の記載と一致した.ただし，Barnett ら って本種の完全型である Pichia kudriavzevii について “variable” と記載された L-sorbose, D-ribose, citric acid の資化性は陰性であり，また，glucono- $\delta$-lactone の資化性は陽性であった，尿素分解能試験に尔いて，培 荃4 日後，わずかに淡紅色を呈した。

\section{(2) Torulopsis etchellsii Lodder et Kreger-} van $\mathbf{R i j}$

菌柇: M-1, $-8,-10$

供試 3 菌株の生理, 生化学的性質は “The Yeasts," 2 nd ed., $(1970)^{(6)}$ および Barnett ら ${ }^{(8)}$ の記載とほぼ一致

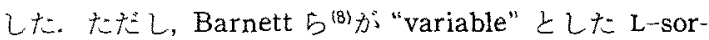
bose，D-ribose，D-mannitol 资化した，しかし， salicin, $d l$-lactic acid, succinic acid を資化しなかった。 ビタミン欠培地に生青し，18\% 食塩培地に生育した。 $37^{\circ} \mathrm{C}$ では生育しなかった。

(3) Candida lipolytica (Harrison) Diddens et

\section{Lodder var. lipolytica}

菌株: M $4,-7$

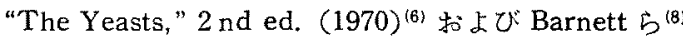
の標準記载と一致した。ただし，本菌種の完全型である Saccharomycopsis lipolytica kつい, Barnett $ら^{(8)}$ よって variable と記载された galactose, L-sorbose, cellobiose， salicin の資化性は，供試菌株においては险 性であり，また，D-ribose は陽珄であった．糖類の発醉 性は認められず， $37^{\circ} \mathrm{C} て ゙ は$ 生育せず，食塩 $15 \%$ では生 育しなかったウレアーゼ活性は陽性で，また，脂質を よく分解した。

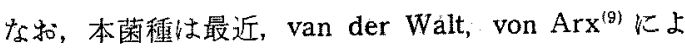
って独立した新属 Yarrowia とされている。

\section{(4) Candida sp.}

菌株: M-11

コロニーはクリーム白，粗面の酔脢状コロニ一、時に 粉状ないし短毛状を呈する，分岥する真菌系と仮性菌系 を形成寸る。菌条側面や頂点に多数の1個ないし数個が 出芽增殖して連鎖した棈円〜長楕円形の blastoconidia を形成する．本菌の詳細な菌学的性質については别に報 告宁百。

\section{(5) Rhodotorula minuta (Saito) Harrison}

菌株 : M-12

"The Yeasts," 2 nd ed. (1970) ${ }^{(6)}$ ⿰氵よび Barnett $5^{(8)}$ の標準記戴之一致した。ただし，Barnett ら “variable" とされた galactose, L-sorbose, cellobiose, ethanol, ribitol, D-mannitol, D-glucitol, salicin, $d l$ lactic acid， succinic acid の資化能は微弱，京た，lactose, D-ribose, inositol および glucono- $\hat{\delta}$-lactone を資 化しなかった。ウレアーゼ活性は陽性，食塩6\%では微 弱な生青であった。

な扰，今後の検討点として熟成中のマイナーな菌相が ある，本報では各熟成期から総計 149 株を分離し，64 株を選択してフローラの変化を挨討しだしかし，各ス テージでの供試株数は平均 10 数株であったことから， フローラ解析のら吝でマイナーなグループをすべて表 しているとはいえないため，今後に検討を加学たいと思 5.

要約

120 日間野菜の漬け込みを繰り返しながら，熟成中の 寁床に扣ける酵母フローラの变化を追跡し，分離酵母の 同定を行った．醉母は糖床調製直後には検出されなかっ

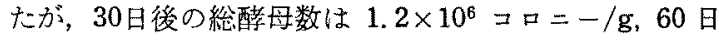
には最大值 $5.9 \times 10^{7}$ コロニー/g に達した。.90日後で は $1.2 \times 10^{6}$ zロ=-/g に減少したものの，それ以降の 顕著な減少は認められなかった. 120 日後の糠床は 2 年 間熟成したそれとほば同じ醉母数であった，各熟成期で の糠床から分離，群別した 64 菌株の5ち，代表的な13 菌株を同定した結果, Candida krusei, C. lipolytica, Torulopsis etchellsii, Rhodotorula minuta 於よび種末 同定の Candida sp. と同定された.

醳母フローラは各熟成期ともC. krusei が優勢で，常 
に 50〜67\% を占め, 次いでT. etchellsii が 20〜30\%を 占めた. Candida sp. とC. lipolytica は，熟成 90 日を 境として交替現象がみられ，前者は90日以前で約 $10 \%$ ， 後者は 90 日以後で約 $10 \%$ の比率で絤出された，120 日間熟成した糠床中心部での主な醭母フローラの比率 は，2 年間熟成した啸床とほぼ同㥞な結果を示した。

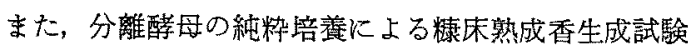
では, C.krusei, C.lipolytica, T.etchellsii が熟成香類

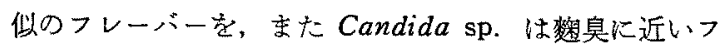
レーバーを生成した。

（1）支倉さつき：栄羡と食䊓，15，353 (1963).

（2）支倉さつき：生活科学，10，15（1974）.

（3）小崎道雄, 小原直弘：昭和 39 年度日本蘑芸化 学会大会講演要旨集, 1964, p. 129.
（4）今井正武, 平野 進, 隻埸美恵子：擩化 57, 1105 (1983).

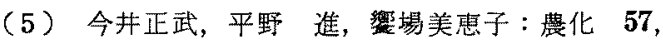
1113 (1983).

(6) J. Lodder (ed.): "The Yeasts, A Taxonomic Study," 2 nd. ed., North-Holland Pub. Co., Amsterdam·London, 1970.

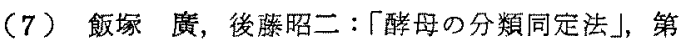
3 版, 東京大学出版会, 1980 .

(8) J. A. Barnett, R. W. Rayne and D. Yarrow: "A Guide to Identifying and Classifying Yeasts, "Cambridge Univ. Press, Cambridge, 1979.

(9) J.P. van der Walt and J.A. von Arx : Antonie van Leeuwenhoek, 46, 517 (1980).

（10）科学技術庁資源調查会：「四訂日本食品標準成 分表 $」, 1982 ，$ p. 54. 